\title{
The Salmon Episodes in \\ Tochmarc Moméra AND Macgnimartha Finn: \\ Les mythes se pensent entre eux
}

Ksenia Kudenko

\section{The salmon episode in Tochmarc Moméra}

The tale Tochmarc Moméra (TM), 'The Wooing of Moméra', belongs to the Cycle of the Kings and relates the adventures of Eógan Taídlech, the eponymous ancestor of Eóganachta who purportedly lived in the second century AD. TM has only one extant manuscript witness - a short manuscript penned by a Lecan scribe Murchadh Ó Cuindlis in the years 1398-9, which now forms part of the Yellow Book of Lecan (H.2.16, alias TCD MS 1318, cols. 281-344). The linguistic features of the tale point towards the last half of the Middle Irish period (ca. 1150-1200) as the possible date of the compilation. External evidence also supports such dating: TM is mentioned in the genealogical tract in the Book of Leinster (TCD MS 1339, fol. 319b, 1l. 42-4), a codex compiled ca. 1160, which suggests that a version of our tale was already in existence in a written form by the middle of the twelfth century. ${ }^{1}$ The first edition of the tale was prepared by Eugene O'Curry (1855). However, it contains a number of mistakes in manuscript transcription and translation, and the poor quality of the first edition has long impeded the critical analysis and full appreciation of the tale.

The story tells about the journey of Eógan to Spain where he goes upon the command of the Spanish druid in order to marry a local princess. The transmarine voyage is motivated by the prophecy that the children of the couple will rule over Ireland. The climax of the story concerns Eógan's physical transformation - he starts shining after putting on a cloak which his wife makes from the skin of a salmon. As a result, Eógan receives a new name, Taídlech, the Shining, and comes back to Ireland as the future king. In this paper, I will try to offer an exegesis of this pivotal event and to show how the comparison with other texts of the same tradition can help us to elucidate this episode. Let us, first of all, look at the text itself. $^{2}$

1. I intend to discuss the manuscript context and possible transmission of $T M$ in my future publication.

2. Transcription of the manuscript and translation are mine. 
Sruth for lár Espáine. Sruth nÉbir a ainm 7 cach sechtmad bliadain tic innti-sene bradán(a) o diamraib na ndúl 7 oland trit-side 7 is andsin ad-bert in dru[i]d cétna:

'Indiu atá $i$ ndán a fagbáil in ni dia mbia in tres ainm ar th' fer 7 ar do chéli 7 eirg dochum in $t[s]$ rotha indiu. i. srotha Ébir 7 indiu atá $i$ ndán in bradán do thuidecht and 7 .uii. mbliadna cusa indiu tánic 7 gabar acut-sa hé 7 ben a olann de.'

O ra-buii Ligbratach ingen ríg Espáine sund 7 .iiii. bliadna aturra sin 7 t'athair-se 7 dixit:

'Erig don tsruth a ainder, Con-ciuchlastar in chaingen,

Co tibre ass tlacht cen meth,

Bid de bias Eógan Taíglech.'

Am-sói docum in tsrotha 7 da-rónadh airceist accu arin mbradán gur gabad léo hé 7 robenad de in tlacht búi fair co nderna si brat dia fir don olaind bói arin mbratán 7 batar na h-uile dath ind isin bratán-sin.

In lathi con-gebed-som in brat uime in dath do-aidbistea don fir bui ina farrad, ni hé ro-taispénta don fhir bud nesa dó-sein. Is andsin fegais in ri fair 7 in inbaid ro-fheg toidliges uile hé itir, étach3 7 erred.

'Darm bréthir,' ol in rí, 'is com-thoidlech ria brat ule Eógan anossa.'

'Cían otá i toicthi 7 i tarrngaire,' ar in drúi, 'in t-ainm-sin do beith fair-sium 7 biaid fair nogo fhadba bás 7 aiged .i. Eógan Toidlech 7 bid ainm iartain dó Eógan Fid[fh]ecach.' (YBL, col. 342, ll. 38-57).

There is a river across the middle of Spain. Its name is the Ebro River, and every seventh year a salmon from the mysterious places of Creation comes into it, and wool [grows] on it. Then the same druid said:

'Today it is destined to obtain something, from which there will be the third name for your husband and your companion. Go to the river today, that is, to the Ebro River, and today it is destined that the salmon will come there, and [it has been] seven years before today [that] it came. And you should catch it and cut its wool from it.' Since Lígbratach, daughter of the king of Spain, was there, ${ }^{4}$ and four years between her and your father, and he said:

'Go to the river, $\mathrm{O}$ woman,

The claim will be heard

So that you would bring from it a garment without decay,

From it will be Eógan Taídlech.'

3. MS ect. I have amended obscure ect to étach, 'covering, raiment, clothing, garment'. My rationale is that the noun étach is acknowledged in the Irish tradition as a synonym of errad (see examples in $e D I L$, s.v. errad), and that such emendation preserves alliteration in the pair of collocated synonyms.

4. Here the scribe probably accidentally skipped a line, and part of the sentence is clearly omitted. 
She went to the river, and a trap was made by them for the salmon, so that it was caught and the skin which was on it was cut from it. She made a cloak for her husband from the wool that was on the salmon, and all colours were in it, in that salmon.

The day the cloak would be put on him, the colour, which would be displayed to the man who was beside him, was not the same that was shown to the man who was nearer to him. Then the king looked at him, and the moment he looked, he [Eógan] all became shining, [his] raiment and vestment.

'Upon my word,' said the king, 'Eógan is as shining now as his whole mantle.'

'For the long time it has been destined and prophesied,' said the druid, 'that he will have this name, and he will have it until he dies, that is Eógan Taídlech (The Shining), and afterwards his name will be Eógan Fidfhecach.'

This episode represents an etymological narrative built upon the derivation of the word brat 'cloak' from the word bratán 'salmon'. The pun was clearly intended by the compiler who sealed this etymology in a phrase co nderna si brat dia fir don olaind bói arin mbratán 7 batar na h-uile dath ind isin bratán-sin 'she made a cloak for her husband from the wool that was on the salmon, and all colours were in it, in that salmon'. In this context, the term brat is understood as a derivative of the noun bratan/ bradán; this etymology fails phonetically as the final consonant of $\operatorname{brat}(t)$ is voiceless, but plays well visually, when the two words are placed near each other in a written sentence.

It might seem that such a paradoxical item as a cloak made of salmon wool was brought into the tale solely to highlight - by means of a narrative - the etymological connection between the two words. The approach, which favours etymological explanation by means of a narrative, was noted by R. Mark Scowcroft (1995: 125) who argued that "words and names inspire narrative ideas in Ireland where Isidore and his followers would prefer analysis and exposition".

The whole episode, I believe, was also inspired by the author's desire to give an explanation for Eógan's sobriquet, Taidlech, 'Shining'. I suppose that originally this nickname might have had a more abstract meaning, referring to the king's glory and superiority, in a sense similar to modern English word 'brilliant'. TM, however, literalises the epithet, and the literal and metaphorical senses merge. Such etymological speculations and the literalisation of tropes is an inherent quality of mythological literature ${ }^{5}$ where "the narrative itself acts out and literalizes the multiple meanings of the words and phrases in question: matter and medium fuse" (ibid., 129).

Another way of interpreting this episode would be to address the words bratán and taidlech from the point of view of their meaning and connotations in the native mythopoetic tradition. The words denoting 'salmon', e.g. eó, éigne, maighre,

5. For the distinction of mythological (abstract) vs. realistic literature, see Scowcroft 1995. 
functioned as poetic simile for a prince or a warrior. From this perspective, Eógan, who, by wearing a salmon cloak, symbolically becomes a salmon himself, represents a visualisation of the trope. As Art Hughes has demonstrated, such metaphors were widely used in bardic praise poetry: "the use of the term 'salmon' is clearly intended as an allusion to a strong, vigorous, warlike, dauntless chieftain" (Hughes 1996: 18). For example, in his panegyrics, Tadhg Dall Ó hUiginn compares William Burke to a 'salmon of the Shannon of bright streams' (maighre Sionna na sruth ngeal) (Knott 1922:159), and Eóghan Óg mac Suibhne - to a 'fortunate salmon from the Finn's stream' (maighre séanta a sruth Finne) (ibid., 190), while Cormac Ó hEaghra is a 'fortunate salmon of the race of Cian' (maighre séanta sleachta Céin) (ibid., 214). In a poem from Acallam na Senórach, Finn is also compared to a salmon: 'then the golden salmon, Finn son of Cumall son of Trénmór, took...' (ar sin ro gab in t-éo óir Find mac Cumaill meic Trénmóir) (Stokes 1900: 72). Similarly, in a poem called $A$ fir ná suidh arin sith found in the Book of Uí Mhaine, Cathal Crobderg and his brother, the last high-king of Ireland Ruiaidrí Ua Conchobair, are praised as "noble salmon who have been attacked by monstrous gairbhéisc (rough fish) who are defined as the Welsh, the English, and the French" (Carney 2008: 689). In another poem devoted to Cathal, Tairnic in sel-sa ac Sil Néill, the sovereignty goddess explains that 'the shoal of big salmon are the princes of Ireland at the drinking feast' (is iat in ré maigred mórl flaithe Eirenn ac in ól) (Ó Cuív 1983: 165, 170). In this vein, the salmon in the Ebro River is a symbol of Eógan himself, and a salmon mantle on the king's shoulders visually manifests Eógan's martial prowess and leadership.

The shining of Eógan's attire can also be interpreted in the context of praise poetry. Physical beauty, often expressed in terms of shining and glowing, was a prerequisite for a king and a standard poetic cliché. Discussing the depiction of regal male beauty, which is an essential ingredient for the acquisition of kingship, Damian McManus (2009: 63) observes that "the emphasis is on dazzling colours, but in particular on dazzling brightness: not of the king's regal bejewelled attire, but of his body itself". Eógan looks like an epitome of this notion: his many-coloured mantle has both dazzling colours and brightness. This glow, together with his association with a salmon, identifies him as the chosen hero and qualifies him for kingship. A similar scenario is used, for instance, to portray Cú Chulainn. First, he is famous for performing a heroic salmon-leap; second, prophetess Fedelm describes him as the one with 'a hero's light on his brow' (luan láith i n-airthiur a chind) (O’Rahilly 1976: 3, 127).

Thus, the salmon episode in TM is built upon etymological expositions - brat bratán; toídliges hélTaidlech; and the notions on which these etymologies are based are organic to the tradition as a whole. The etymologisation of poetic tropes here literalises and re-actualises the already existing metaphorical parallelism between a hero and a salmon, and the topos of bright glow which singles out a hero or a lawful 
king. I would argue, however, that the image of a salmon cloak, which, I believe, evoked the same wonder in the tale's medieval audience as it does in us, is too captivating and memorable to be simply a word-pun or a visualisation of poetic clichés.

The main question, therefore, concerns the significance of the cloak. Why was it crucial to introduce this image into the narrative? Why was the cloak made of a salmon skin, and why did it cause Eógan's physical transformation? To answer these questions, it might be useful to look at other stories which feature a similar range of motifs: they will probably have something to say about the salmon of our story.

\section{The salmon episode in Macgnimartha Finn}

The salmon in TM plays the role of the transforming agent in Eógan's rite de passage from a young boy, maccóem, to a royal figure; and an initiatory scenario underlies the plot of the whole tale. ${ }^{6}$ For those familiar with Irish tradition, the salmon episode has immediate associations: probably the most famous Irish tale which features both the salmon and the change in the hero's status is the late twelfth- or early thirteenth-century Macgnimartha Finn $(M F)$, 'The Boyhood Deeds of Finn', "short incomplete text included in a fifteenth-century manuscript known as Codex Laud 610, housed in the Bodleian Library of Oxford University" (Nagy 1985: 7). This tale is our first source where Finn obtains poetic function by burning his thumb on the salmon of knowledge (Murray 2017: 119). ${ }^{7}$

In this account, young Demne, gilla of Finn Éices, ${ }^{8}$ waits on the bank of the Boyne River for the salmon of knowledge, which he has to catch for his master. The magical creature brings the gift of poetic knowledge and prophecy to the one who consumes it. Eventually, the salmon is caught, and Finn Éices orders

6. According to Van Gennep's definition, rites of passage consist of three phases, namely, 'separation', 'transition' and 'reincorporation' (Van Gennep 1960:11). This corresponds to the main stages of Eógan's journey. First, he leaves Ireland for Spain, spends a year abroad, and returns back to his country as the king of Leth Moga, the southern half of Ireland. Interestingly, Cath Maighe Léna, a later and longer version of Eógan's heroic biography, employs another scenario:Eógan is banished from Ireland and is forced to go to Spain after he loses a battle with Conn Cétchathach. Thus, an 'expulsion-return' formula is chosen here as a life-pattern of a hero, "a standard part of the heroic biography is a story of expulsion and return, a trip abroad" (Sproule 1985: 17). Ó Cathasaigh also distinguishes political level in the interpretation of heroic myth based on the 'expulsion-return' formula: "the hero returns to his birth-place, overcomes his persecutor, and deprives him of his kingdom. This is indeed a constant theme of the political literature of early Ireland" (Ó Cathasaigh 1977: 13). Notably, giving examples of heroes and their divine opponents on p. 14, Ó Cathasaigh mentions Conn in the category of Otherworld gods. From this point of view, TM and Cath Maighe Léna represent heroic myths, where a hero, Eógan, returns to Ireland to confront his enemy Conn and to take over his father's kingship in Leth Moga.

7. An edition of this tale was prepared by Kuno Meyer (1881-3); the translation is given in Meyer (1904); for a more recent translation see Nagy (1985: 209-18), Carey \& Koch (2003: 194-201).

8. For the discussion of the term gilla, see Nagy (1985:125ff). 
his apprentice to cook it. Because of the precious essence of poetry contained in the salmon, eating the fish is strictly forbidden to Demne. However, while cooking the fish, the boy accidentally burns his finger and puts it in his mouth to cool it down. As Joseph Nagy explains,

the cook puts a part of himself that has been 'cooked' in his mouth almost as a parody of eating. In this way Demne acquires and consumes the poetic inspiration and knowledge meant for his teacher. The gilla actually assumes his master's identity: upon realizing what has happened, Finn the Poet gives the salmon and his own name to Demne.

(Nagy 1980: 125)

In the fiannaiocht tradition, the salmon comes from Linn Féic in the River Boyne, the waters of which carry the otherworldly nuts of wisdom (in TM the salmon also comes from 'the mysterious places of Creation'); the fish contains the quintessence of poetic inspiration which the recipient obtains through consuming it. In the story of Finn, "the salmon has not yet completed its passage from the extra-social source of poetry to the representative of society, the poet; before the latter can consume it and utilise the poetic essence within, the gilla must cook the fish" (ibid., 127). In this case, the procedure of cooking is an indispensable intermediary stage which transforms the Otherworld substance into the product consumable in this world. If we consider the process of cooking as a cultural technique which domesticates raw or alien substances and makes them usable for people, representatives of culture, it is typologically similar to making clothes, when animal skin is made part of material culture by turning it into fabric. The shift from 'nature' to 'culture' in the episode of making a cloak out of the salmon skin is as obvious as in the episode of cooking a raw fish. A creature as fantastic as a woollen salmon is transferred into a socially acceptable form of a king's mantle. After that, Eógan's own identity comes into being.

\section{Le cru et le cuit}

In his analysis of the significance of cooking in the story of Finn, Joseph Nagy (1980:124; 1985: 15, 132) often refers to the seminal study by Claude Lévi-Strauss, Mythologiques I: Le cru et le cuit (published in English as The Raw and The Cooked). In the opening sentence of the introduction to the volume, Lévi-Strauss explains that

des catégories empiriques, telles que celles de cru et de cuit, de frais et de pourri, de mouillé et de brûlé, etc., définissables avec précision par la seule observation ethnographique et chaque fois en se plaçant au point de vue d'une culture particulière, 
peuvent néanmoins servir d'outils conceptuels pour dégager des notions abstraites et les enchaîner en propositions.

(Lévi-Strauss 1964: 9) ${ }^{9}$

Through the observation of these dichotomies in various myths, Lévi-Strauss strives to unveil the epistemological principles which are timeless and ubiquitous, in other words, those that are valid for any group of people, anywhere and anytime. Ultimately, it becomes possible for him to categorise myths according to ideas they convey with the help of these basic binary oppositions, and to acknowledge that universal laws must govern mythical thought. According to his striking statement, "peut-être, ainsi que nous avons suggéré, convient-il d'aller encore plus loin, en faisant abstraction de tout sujet pour considérer que, d'une certaine manière, les mythes se pensent entre eux" (Lévi-Strauss 1964: 20, my emphasis)..$^{10}$ A reviewer of Le cru et le cuit François-André Isambert was obviously attracted by this formulation and gave his own more detailed explanation:

Un mythe est la traduction d'un autre, dans la mesure où il en est la transformation selon des règles précises. Et ces transformations sont éclairantes dans la mesure où elles mettent en lumière des articulations essentielles, des invariants fondamentaux. En ce sens, on peut dire que "les mythes se pensent entre eux". ... Ainsi un ensemble de mythes forme un système lorsqu'ils fournissent les solutions d'une même combinatoire et sont, à ce titre, complémentaires entre eux. ${ }^{11}$

(Isambert 1965: 393, my emphasis)

The common invariant, which underlies a group of myths, as well as their

9. 'Empirical categories - such as the categories of the raw and the cooked, the fresh and the decayed, the moistened and the burned, etc., which can only be accurately defined by ethnographic observation and, in each instance, by adopting the standpoint of a particular culture - can nonetheless be used as conceptual tools with which to elaborate abstract ideas and combine them in the form of propositions' (Lévi-Strauss 1970:1).

10. It is not easy to translate such an elegant and concise phrase into other languages, primarily because the particle se can express both reflective ('myths think themselves') and reciprocal ('myths think each other') relations. The English translators have preferred to paraphrase the final part as follows: "and, as I have already suggested, it would perhaps be better to go still further and, disregarding the thinking subject completely, proceed as if the thinking process were taking place in the myths, in their reflection upon themselves and their interrelation" (Lévi-Strauss 1970:12). Zafiropoulos (2010:171) gives a slightly different translation, and summarises Lévi-Strauss's idea as "myths think themselves in relation to each other by the intermediary of men".

11. 'One myth is a translation of another insofar as it is its transformation according to the precise rules. And these transformations are enlightening insofar as they shed light on the essential articulations, fundamental invariants. In this sense, we can say that "myths think themselves among each other." ... Thus, the ensemble of myths constitutes a system when they provide solutions for the same combination and are, as such, complementary to each other' (translation is mine). 
self-reflective and introspective character were also noted by René Girard in his article about Lévi-Strauss's critical theory:

Lévi-Strauss also says that myths are able to think each other as myths. The formula has been most successful but its real meaning is not explained. It cannot mean only that many variations of the same myth are found. In nature, many varieties of the same species are found, many varieties of ants, for instance, but we would not say that these different ants think each other. In order for myths to think each other, it is necessary that each myth, up to a point, think itself as myth. And myths appear to think themselves because they provide the mirror in which they reflect their own process. Since the process is one of pure differentiation, the only appropriate mirror is the undifferentiated. ... It is the presence in myths of the undifferentiated that allows Lévi-Strauss to say that they "think each other as myths".

(Girard 1977: 113, my emphasis)

The ideas first conceived by structural anthropologists and Claude Lévi-Strauss have inspired literary studies worldwide, and, although they are not mainstream nowadays, the structuralist approach has also considerably advanced the study of Celtic literatures. One of the first scholars to introduce the structuralist methodology (originally pioneered in linguistics by Ferdinand de Saussure) into Celtic Studies was Marie-Louise Sjoestedt. In her book Dieux et héros des Celtes (Sjoestedt 1940) (Gods and Heroes of the Celts in English translation (Sjoestedt 1949)), she has chosen systemic analysis to establish a classification of Celtic mythological and literary personages based on binary oppositions. As Tomás Ó Cathasaigh (1977:11) comments, her approach reflects "the belief that there is a basic binary structure in all forms of human communication, a belief that has been applied to the study of mythology by Claude Lévi-Strauss and others." He thereafter defines Lévi-Strauss's structuralist theory using the words of Edmond Leach: "binary oppositions are intrinsic in the process of human thought, and every mythical system is a structure built upon certain central antinomies." Sjoestedt's work remains a valuable contribution to the study of Celtic literatures and mythologies, and, what is more important for the present discussion, "Marie-Louise Sjoestedt briefly but effectively demonstrated the usefulness of structural anthropology for the interpretation of early Celtic literatures" (Scowcroft 1995: 121).

Structuralism has also stimulated research of underlying basic narrative structures, instead of reconstructing ideal $U r$-texte, which, as was initially thought, were corrupted and blurred in imperfect texts handed down to us:

The initial, textualist urge to postulate specific mythological prototypes, any deviation from which in the extant sources bespeak error or wilful intervention, has 
gradually yielded to the recognition of what James Carney calls 'abstract story-patterns' and Proinsias Mac Cana calls 'thematic cores': narrative conventions in a living tradition rather than the rubble of a misunderstood canon.

(Scowcroft 1995: 121)

This idea of a narrative pattern, or fabula, on which various stories can be based, has deepened the interpretation of early texts, and manifested "the trend toward modified structuralism in Irish scholarship" (ibid.).

Another key text relating to the history of structuralism in Celtic Studies is Tomás Ó Cathasaigh's monograph Heroic Biography of Cormac mac Airt, in which he addressed multiple realisations of the international heroic pattern in diverse literary contexts. His analysis has proven that a specific story-pattern is not a religious dogma but an archetype, which is able to generate innumerable variations. Ó Cathasaigh has also elaborated O’Rahilly's “two-fold typology, the types being designated hero and Otherworld god", explaining his own methodology by the fact that "we can best discuss this theory, and discover its implications, if it is restated in structuralist language" (Ó Cathasaigh 1977:14). He recasts O’Rahilly’s model in a system of binary oppositions which can be in paradigmatic or syntagmatic relationship in the structure of a myth.

Northrop Frye's opposition of abstract and representational narrative designs (Frye 1957: 131 ff) was applied to medieval Irish compositions by R. Mark Scowcroft. Frye adapted the structural anthropology of Claude Lévi-Strauss to literary theory, and distinguished a dichotomy of myth and realism, which corresponds to the binary opposition of abstract vs. imitative art. Scowcroft made an attempt to trace examples of abstract modality in Irish mythological narratives, and defined it as follows:

The difference between abstract and mimetic narrative does not amount simply to the presence or absence of the fantastic but to the attention given to internal versus external rules of design. Abstract narrative focuses on elements of the medium itselfstory-patterns, motifs, principles, themes, metaphors and other verbal associations.

(Scowcroft 1995: 122)

The abstraction of story-patterns allowed them to endure in the tradition and ensured their versatility in serving "as vehicles for various themes in a wide range of literary genres, contexts, addressed to many different audiences, and as flexible as they are effective" (ibid., 154-5). This scenario ultimately illustrates Lévi-Strauss's theory that myths reflect each other and think themselves in relation to each other. Since same story-patterns were adapted to a variety of personages, places and events, the comparison of two seemingly different stories allows scholars to discern the core which they share, allowing us to better understand these narratives and the role of their constituent elements. 
Donnchadh Ó Corráin has very convincingly shown that the scenarios involved in Irish narratives were limited and repetitive, and were subject to a unified mode of treatment rather than to an original interpretation on behalf of their compilers. "Once an appropriate formula had been devised, one had only to change the details to meet new situations" (Ó Corráin 1986: 143). Therefore, if we look beyond varying circumstances, we get a stable narrative pattern as a literary tool suitable for multiple applications. The thematic correspondences in various tales, however, do not imply their common origins. As Pádraig Ó Riain puts it,

the repetitious nature of Irish literature in thematic terms is not necessarily indicative of a widespread literary course of derivation. Rather should it be taken as a reflection of the perennial Irish concern with a limited group of themes, and with the less limited, though by no means extensive, area of possible manoeuvre in the introduction of thematic variables.

(Ó Riain 1972a: 181)

Notably, Lévi-Strauss has ascribed a general character to this phenomenon. In his monograph La pensée sauvage (The Savage Mind) he describes the 'bricoleur model' of common mythological thinking, which in many ways echoes Ó Riain's statement:

The characteristic feature of mythical thought is that it expresses itself by means of a heterogeneous repertoire which, even if extensive, is nevertheless limited. It has to use this repertoire, however, whatever the task at hand because it has nothing else at its disposal. Mythical thought is therefore a kind of intellectual 'bricolage' - which explains the relation which can be perceived between the two.

(Lévi-Strauss 1966: 16-7)

The main advocate of structuralist anthropology in Celtic Studies is Joseph Nagy whose book The Wisdom of the Outlaw is considerably influenced by Lévi-Strauss's ideas. In the introduction to the volume, Nagy (1985:10) mentions contemporary anthropology as a valuable approach to the study of myths. Based on the premise that "every story has something to say about every other story within the tradition", structuralist methodology welcomes a holistic approach to the material of the corpus. In this vein, Nagy carries out a comparative analysis of various texts belonging to the Fenian Cycle in order to distinguish the main unifying patterns and motives intrinsic to the Cycle as an organic whole. As he assumes "the affinity among Fenian stories separated in time and space, and the unconscious dialectic shared by them" (Nagy 1985: 15), his "primary aim is to examine a group of narratives in the context of a narrative tradition and to explore their internal consistency" (ibid.,14). The explanation of his chosen approach is worth quoting in full: 
The present study was undertaken partly in order to demonstrate how naturally Gaelic traditional story lends itself to the structuralist method of narrative analysis, most brilliantly employed in the mythological studies of Lévi-Strauss. Briefly, the hypothesis behind this method is that within a narrative tradition, at any given point in its historical span or throughout that span, every story has something to say about every other story within the tradition. Every tale, accordingly, can be treated by the mythologist as a multiform of every other, just as every story, in both a thematic and structural sense, "flows into" every other. The method derived from this structuralist hypothesis encourages the analyst to ascertain the meaning of a story, its fundamental, ahistorical "truth", on the basis of the other stories within the tradition. The structuralist interpretation of myth is in fact a process of translating one story into another, a process that can be as complex as the narrative tradition itself. In the course of attempting such translations we gradually arrive at the outlines of a "language" continually exercised within the narrative tradition.

(Nagy 1985: 15)

Eventually, Nagy expresses his hope

that in the following examination of but a seemingly single strand of the vast web of Fenian narrative tradition, the reader will discover the narrative language underlying the entire tradition, as well as some of the major ways in which this Fenian language fits into the larger patterns of meaning within Gaelic narrative tradition and culture.

(ibid., 15-6)

The Fenian Cycle is part of a much wider tradition, the same tradition which produced TM; and since all the stories in the tradition are interconnected, the comparison of $T M$ with a Fenian tale might bear fruit, because both texts are compiled using the same "narrative language". In his review of The Wisdom of the Outlaw, Scowcroft has endorsed the chosen "Lévi-Strauss's method of analysing a single narrative as the expression of its traditional matrix - what in literary terms could be called the larger hermeneutic circle of text and tradition" (1987: 98). In this sentence, Scowcroft reconciles the views of Lévi-Strauss with the literary theory of the narrative tradition and the medium at its disposal, as described, for example, by Donnchadh Ó Corráin (1986). The native tradition consists of a limited range of story-patterns which are then developed in different ways in different stories. This premise is the reason why every story has something to say about any other: after all, they are all based on the same motifs and literary conventions, which Lévi-Strauss reduces to a number of binary oppositions.

While sympathising with Lévi-Strauss's approach in general, Nagy particularly stresses the importance of the 'raw and cooked' dichotomy: 
As the anthropologist Claude Lévi-Strauss has amply demonstrated, cooking and fire in myth and ritual often represent the process of socialization ... in the language of myth and ritual symbolism, that which exists outside society or is not entirely social is designated "raw", while that which exists within society and has an identifiable social function is designated "cooked". Metaphorically, therefore, the savage who lives beyond society and the youth who is not yet an adult and does not enjoy a complete social identity, are both "raw" and must be "cooked"-culturally transformed - before they can fully become members of society.

(Nagy 1985: 132)

For instance, Nagy interprets in this light the image of Dercc Corra who is portrayed as a gilla of the fiana in the tale 'Finn and the Man in the Tree'. While Dercc Corra was preparing food for the Fenian warriors, he used to jump over the cooking pit back and forth, and "leaping over the pit therefore symbolizes his going from raw to cooked, from nature to culture, from childhood to adulthood" (ibid., 133).

Speaking of other examples of structural analysis in Celtic Studies, the exegesis of Echtra Nerai following Lévi-Strauss's theory was undertaken by Alden Watson (1986). More recently, Leonie Duignan carried out "a comprehensive textual, intertextual and comparative analysis" of the echtrae genre on the basis of LéviStrauss's methodology. As she explains, "this method takes a given myth, reduces it to its smallest component parts (which he calls 'mythemes', usually one event or position in the story of the myth), whereby each component exists in relation to another" (Duignan 2011: 8).

Therefore, structuralism has proven to be useful for the interpretation of Celtic literatures. 'Undifferentiated' of Girard, or Isambert's 'fundamental invariant' correspond to 'fundamental, ahistorical 'truth" of Nagy, and to Carney's 'story-patterns', signifying a stable changeless element which lies at the heart of corresponding mythological tales. If we apply this methodology to the two tales in question, the salmon episodes in $T M$ and $M F$ seem to share this unvarying core. The comparison of these tales allows them to interact effectively and to explain both themselves and each other. The basis of both accounts is modelled upon the following invariant fondamental: the process of the culturalisation of a wild salmon from raw to ready (to wear)/cooked mediates the protagonist's passage between nature and culture, between the Otherworld and this world and, ultimately, between adolescence and adulthood. Thus, the mythological mindset is holistic and building on a simple opposition from everyday life, it creates a bricolage of pairs of dialectic notions. Mythological narrative here serves as a vehicle for explanation.

That, from the mythological point of view, cooking and sewing are different realisations of the same transitional process was well documented by Lévi-Strauss himself. Already at the end of his first volume, Le cru et le cuit, in the chapter called Noces ('Wedding'), he mentions that the culinary opposition 'raw/cooked' is 
subsequently associated with the 'naked/dressed' dichotomy. For example, he notes that in France the young people who wanted to get married were to eat salad made of raw vegetables, while in England a single person was to dance without shoes; therefore, the comparison of these rituals equals the categories of 'raw' and 'naked'. Further on, he stresses that this equivalence is often reflected in idiomatic constructions. Lévi-Strauss quotes such idioms as English 'to sleep in the raw' meaning 'to sleep naked', or French danser à cru meaning 'to dance barefoot' (Lévi-Strauss 1964:340-1). The fourth and last volume of his Mythologiques entitled L'homme nu, 'The Naked Man', is entirely devoted to this idea (Lévi-Strauss 1971). Throughout this volume, Lévi-Strauss argues that culture as such is identified not only with cooking food but with making clothes as well. Hence, the dichotomy of 'raw' and 'cooked' implies the notions 'naked' and 'dressed'. Among many other examples, he cites a tale about the Eagle and the Coyote. With the help of a cunning trick, the latter makes the Eagle dispose of his clothes and appropriates both his feathery dress and his identity (Lévi-Strauss 2007: 238). As Lévi-Strauss observes, by doing so, the Coyote forces the Eagle to degrade from culture to nature, and, metaphorically, from food cooked on fire to a raw food diet (ibid.,327). ${ }^{12}$

Therefore, from the perspective of their structure, the stories of Finn and Eógan are moulded upon the same main theme - the social maturation and transition of the hero is mediated by his contact with the mystical essence contained within the salmon. For both Finn and Eógan the interaction with the final product of the salmon's transformation manifests the accomplishment of their rites of passage. As a result, both heroes receive new names straight after: gilla Demne becomes Finn; and prince Eógan receives his predestined name Taídlech. The change of the name in this case indicates the hero's new status of an enlightened poet and prophet and of a king respectively, and shows that the protagonist's identity has been shaped. As Kevin Murray (2017: 140) observes, "the hero's acquiring a new name... may be understood as representing 'a rite of incorporation' into adult society." The reception

12. There is also, apparently, a psychological convention that being naked affects the status of a person in the most negative way. Cf. this striking passage from The Brothers Karamazov:

Ему было нестерпимо конфузно: все одеты, а он раздет и, странно это,-раздетый, он как бы и сам почувствовал себя пред ними виноватым, и, главное, сам был почти согласен, что действительно вдруг стал всех их ниже и что теперь они уже имеют полное право его презирать (Ф. М. Достоевский. Братья Карамазовы. Книга 9, глава 6, «Прокурор поймал Митю»).

He felt unbearably awkward. All were clothed, while he was naked, and strange to say, when he was undressed he felt somehow guilty in their presence, and was almost ready to believe himself that he was inferior to them, and that now they had a perfect right to despise him (F. M. Dostoevsky, The Brothers Karamazov. Book 9, Ch. 6, 'The Prosecutor Catches Mitya') (transl. Garnett 2005: 446) 
of a new name is symbolic insofar as it manifests the crucial change in personality: " His [Finn's] acquisition of a new name, so intimately bound up with his attainment of poetic and prophetic function, is a central part of his evolution from the wilderness of his childhood to his role as the leader of the fiana" (ibid., 151). As Joseph Nagy (1981:12) puts it, "he has specifically become a poet and receives a new name as an indication thereof."13

Note, however, that, pace Nagy, Finn is in "a perpetual state of 'pre-adulthood', which both gives Finn unique anomalous characteristics and precludes him from membership in society" (Nagy 1984:30); and his "new name is not a token of social membership but rather of the youth's estrangement from the civilized world" (Nagy 1985: 123). Since Finn is never fully integrated into society and continues his life on the borderline between civilisation and wilderness, a more appropriate parallel to the initiation of Eógan, as described in $T M$, is found in the story of Cú Chulainn. Young Sétanta also receives a new name which encapsulates his destiny - he becomes a guard hound of Ulster. He travels to a foreign land where his initiation in martial arts takes place. Similarly to Eógan, "to achieve adulthood Cú Chulainn must go beyond society and experience the kind of 'fosterage' or instruction which the young Finn experienced" (Nagy 1984: 31). After that, "Cú Chulainn can marry and thus become fully an adult male member of society" (ibid., 30). Finn, Cú Chulainn and Eógan all receive their names from druidic figures. Cú Chulainn receives it in the community which he is about to join; Finn gets his new name in the liminal area at the bank of the Boyne, and he preserves his borderline status till the end of his life. Eógan, however, receives his new name in a foreign land, since, echoing the Milesian legend, TM legitimises the king by means of his Spanish connections. "Since the druid/craftsman - who receives his powers from extra-social sources but exercises them for social purposes - is an ambiguous and ubiquitous figure, he can perform this defining function for either hero in either context" (ibid., 38-9).

\section{Seeing the big through the small: 'raw/ naked' vs. 'cooked/ dressed' in other tales} Since the mythopoetic tradition expresses various ideas by rearranging a limited

13. In Finn's case, this is not his first nickname. In the beginning of $M F$, gilla Demne loses his hair as a result of a disease and receives a nickname Mael, 'bold'. Nagy (1981: 8-9) explains how the name Mael encapsulates Demne's position and social status. Interestingly, similar to Eógan, Demne also gets this nickname after an evident physical transformation. In general, the concept of renaming or a true name is well attested in world literature and folklore, e.g. when the knowledge of a name gives power over someone's fate, like in German folk-tale Rumpelstiltskin, or in English Tom Tit Tot, or when there is a taboo to ask for someone's name, like in the case of Lohengrin. The change of a name as a sign of the change in status is frequent in the Bible: thus, Jacob receives a name Israel after his encounter with God (Gen 32:28); and Abram is renamed Abraham which symbolises God's promise that he is to become the father of many nations (Gen 17:5). 
number of motifs, we can expect to find the realisations of the 'raw and cooked' dichotomy in other stories, the analysis of which might also assist in interpreting the salmon episodes in $T M$ and $M F$. For this reason, I will proceed to the discussion of other Irish and international tales which seem to contain a relevant basic binary pair of 'raw' and 'cooked' which encapsulates a larger 'nature' (illogic)/ 'culture' (logic) dichotomy with the implication of the relationship between Otherworld and the real world, immaturity and adulthood, and so on. First of all, this opposition is evident in folklore accounts on how a mortal man is trying to seduce a supernatural woman by offering her different types of bread. These were discussed by Proinseas Mac Cana in his article 'The Irish Analogues of Mélusine' and include Welsh and Irish fabulates (Mac Cana 1999). The basic plot of these tales is as follows: a man sees a beautiful lady and invites her to come with him. He offers her baked bread but she rejects. The next day he brings her unbaked bread but the result is still unsatisfying. Eventually, on the third day, he brings lightly baked bread - as the Irish story phrases it, "just to put the bread on the griddle and lift it off". The supernatural woman accepts the food and becomes his wife.

The baked bread is a metaphor of our world and of human culture, while the unbaked bread symbolises the Otherworld - the realm of immortals which is an inverse image of the earthly life. Therefore, the lightly grilled bread that is neither cooked nor uncooked represents the coincidence of mutually exclusive elements and provides a platform for a union between mortals and supernatural beings: "on the functional level, to win the fairy woman through the choice of the ambiguous bread is essentially the same as to capture her within the ambiguous space" (Mac Cana 1999: 153). ${ }^{14}$ Another variation of this tale, the Welsh story of Llyn y Fan, is discussed by the Rees brothers in Celtic Heritage: "coincidence of opposites and of other irreconcilables gives a shock to the understanding and transport the spirit to the gateway of the Other World" (Rees \& Rees 1961:344).

The comparison of some other tales also demonstrates the typological equivalence of cooking and making clothes as two transforming cultural techniques par excellence. This significant correlation is found, for example, in the story of Mis and Dub Ruis, on the one hand (Ó Cuív 1954; Partridge 1980:25-6; Carey \& Koch 2003: 282-5), and Mór Muman 7 Aided Cuanach meic Ailchine, on the other (O'Nolan 1912-3). In the first tale, Mis has gone mad after the death of her father and lives in the forest. She is restored to her senses after eating the deer which she catches (the second restorative element is the coition with Dub Ruis). Initially, the girl wants to eat the deer raw (the madness and wildness of Mis correspond to this basic category) but her lover Dub Ruis insists that the deer should be cooked before consumption (clearly, Dub Ruis is a representative of reason which correspond to the 'cooked'

14. I will discuss liminal spaces later on in this paper. 
element of the dichotomy). Therefore, the shift from nature to culture and from madness to sanity is here expressed in terms of cooking. However, the same conflict in the story about Mór Muman has another resolution. Like Mis, Mór goes astray, but her return from frenzy is manifested by her acceptance of the queen's cloak (Mac Cana 1955-6: 84). Thus, the relevant change from chaos to culture and from madness to reason is described in categories of nudity and clothing. Interestingly, Seán Ó Coileáin compares the story of Mór Muman to the confession of Caillech Bérri lamenting her poor clothes, and explains this motif in relation to the acquisition or loss of power and social status:

There is a remarkable emphasis on clothing imagery in both this text [the story of Mór Muman] and the Caillech's poem. Mór wanders about Ireland in rags; on going to bed with Fíngin mac Áeda she discards them; her new position as queen is confirmed by placing a purple cloak about her. The Caillech describes the reverse process in such stanzas as:

Is mé Caillech Bérri, Bui;

no meilinn léini mbithnui;

indiu táthum dom shéimi,

ná melainn cid aithléini. ${ }^{15}$

(Ó Coileáin 1974: 114-5)

A parallel to the stories of Mór Muman and Eógan, who undergo positive transformations after putting on a royal cloak, is found in Togail Bruidne Da Derga. In one of the episodes, Conaire is going to Tara naked, and messengers are waiting for him to put the royal mantle on his shoulders (Knott 1936: 5; trans. Stokes 1901: 25). By accepting the garment, Conaire simultaneously accepts the power, and the "laying of the royal raiment upon the would-be king" symbolises "his acquisition of a kingly status" (Fomin 2010b: 228). Thus, the shift from 'naked' to 'dressed' implies the rise to a higher social status, as well as the shift from adolescence to maturity.

In the Middle Irish Fenian tale Feis Tighe Chonáin, 'The Feast of the House of Conán', the acquisition of appropriate clothes also mediates the passage between the two worlds: in this case, Finn is accepted by the Otherworld society. In one of the episodes, Finn is named Giolla-na-gCroiceann, Lad of the Skins, as he is wearing only skins of slain deer (O'Kearney 1855:130-1). One day he sees an assembly of beautiful women standing on the edge of a cliff. Whoever wants to win the love of one of them must perform a leap over the valley between the two precipices.

15. 'I am the Caillech Bérri beside Dursey / I used to wear an ever-new tunic / today I have for my thinness / that I may not wear out even a worn-out garment.' The translation is quoted after Ritari 2006:67. 
Finn leaps over the chasm, and the sidh-woman named Donait welcomes him as her lover:

Do bhuain mo chroicinn diom, agas tug éadach mo dhiongbhála dham, agas do rug lé d'a tigh féin mé an oidche-sin

'She stripped me of my skins, gave me fit clothing, and brought me to her own house that night.'

(O’Kearney 1855: 132-3)

As Nagy (1985: 120) comments on this passage, "Finn literally sheds his rough-hewn identity as the Lad of the Skins and puts on the clothes of the otherworld, given to him by his lover." Here again, the change of clothes visually manifests an abstract idea, Finn's acceptance by the Otherworld and the crossing of a threshold between the worlds.

In contrast to Eógan and Conaire, who put on regal attire as a visual manifestation of kingship, the protagonist of Buile Shuibne loses his royal status and, echoing Mis and Mór Muman, his mind, after losing his cloak. When the enraged king Suibne hastens to the newly founded church of St Ronán, he drops his cloak and comes to the site stark naked. Deprived of his royal mantle, Suibne is already symbolically deprived of his status, his kingship and his senses, this being followed by St Ronán's curse which turns him into a geilt and a madman for real (O'Keeffe 1913:5). In this example, the descent from 'dressed' to 'naked' symbolises the decline from reason to madness, from high social status to marginal existence, and from settled life within the confines of society to wandering in the wilderness.

Irish tradition also provides an interesting counter-example to the story of Finn and the salmon. In the vernacular Life of St Brendan, there is an account of a man called Dobarchú (lit. 'water-dog' or 'otter') (Plummer 1922, i: 81-3; ii: 79-80). Like Finn, Dobarchú is cooking a trout he caught in a lake but, unfortunately for him, he ignores the social norms which prescribe a particular way of cooking on fire. First of all, he makes a fire of bracken. Moreover, he eats the hot fish straight off the spit. After that, Dobarchú rushes to the river to quench his thirst but falls into the water and turns into an actual otter. Similarly to the situation I have just referred to in Buile Shuibne, this metamorphosis is the result of the saint's curse. While Finn successfully performs the significant transformation of the salmon from 'raw' to 'cooked', and makes progress in his social position, Dobarchú violates the basic rules of cooking and experiences a decline from human to animal, in other words, the shift from 'culture' to 'nature'. In a poem, an otter Dobarchú warns his son that he must not, under any circumstances, make a fire of fern and eat a fish hot without waiting for it to cool down. Moreover, while in the story of Mis the properly cooked meat returns the mad woman to her senses, Dobarchú, on 
the contrary, loses his mind. He laments that he is now gan cheill, 'without sense', because the hot fish has burned him. ${ }^{16}$

The opposite transformation of an animal into human perceived through the cultural activities of cooking and sewing/weaving is experienced by the main heroine of the Russian folk tale The Frog Princess (Afanasy'ev 1985). In it, the three royal brothers are engaged in shooting three arrows, and the girl who finds an arrow will become the wife of the prince who shot it. The arrows of the two elder brothers land in the yards of a nobleman and a rich merchant, while the arrow of the youngest brother lands in a bog and is found by a frog. The latter turns out to be a princess who becomes a beautiful woman after putting off her frog skin. The old king, the father of the three brothers, sets special ordeals for his daughters-in-law. The first task is to bake a loaf of bread; the second one is to sew a carpet. As Maxim Fomin observes, the supernatural frog:

behaved like a human, and was transformed into a human for the duration of the time taken to perform her tasks. The observed semiotic models embedded into such a narrative core can be explained by analysing the motivation behind the activity of the main character. According to Yury Lotman (2000:334), "a human being, immersed into a cultural space, inevitably creates an organised spatial sphere around himself. This sphere, on the one hand, includes ... semiotic models, and, on the other, the re-creative activity of a human." Thus, the Frog Princess, being brought from the bog and finding herself in the cultural space of a human society, is bound to act according to its norms and regulations. She is only brought into human shape when she engages in various forms of activity central to human existence.

(Fomin 2010a: 261)

Likewise, Lévi-Strauss's pattern which I have referred to above can be identified in this tale. The frog takes the shape of a woman when she puts off her skin; nevertheless, she becomes fully human only after being involved in baking and carpet weaving - traditional female cultural activities. Significantly, baking and weaving in this tale are associated with kingship - the carpet the frog makes is ornamented with the image of the royal capital and the bread has the model of the city on its top. By doing this, the frog princess helps her husband to conquer the kingdom and manifests her own queenly character.

Probably the same motif of the inclusion of an Otherworld woman into this world through performing traditional female tasks can be found in the beginning

16. Significantly, in an article devoted to the image of a madman in Irish literature, Ó Riain lists "the consumption of contaminated food or drink" as one of the reasons for madness (Ó Riain 1972a:183, 191); by contrast, "the consumption of 'blessed' food or drink" in Ó Riain's scheme restores to sanity (ibid., 184, 202). 
of the tale Noinden Ulad. In it, Macha ${ }^{17}$ chooses an Ulster commoner Crunnchu as her husband and comes to his house. As Joanne Findon observes in her recent article about the relationship of Otherworld women and mortal men,

Macha does not focus on self-display but immediately enters the home and identifies herself with Crunnchu's domestic space: she walks righthandwise around the kitchen (signifying good luck), then silently sets about performing household chores such as kneading dough and cooking a meal. At the end of the day she goes out and milks the cows, and when night falls she lies down beside Crunnchu and initiates a sexual relationship with him. Although there is no mention of her being paid her bride price, she clearly becomes his wife.

(Findon 2017: 120)

In a footnote, Findon expresses a certain surprise that "Macha performs domestic tasks that would not normally be associated with a woman of elite status (as Otherworld beings tend to be)", and stresses that in Irish sources female physical work is viewed "as being beneath the dignity of noblewomen." This paradox can perhaps be explained in the light of Lévi-Strauss's theory, and by comparing this tale with The Frog Princess. Like the magical frog, supernatural woman Macha makes herself able to become a wife for a mortal man after she engages in traditional processes of making dough and cooking food. Only after that she has an intercourse with Crunnchu, an ultimate step which makes her part of the mortal world. Here the shift from raw to cooked, as well as coition, mediates Macha's own shift from the Otherworld to this world.

I believe that the transformation of a sovereignty goddess from a loathly lady into a beautiful woman in the central kingship myth, the 'king-and-goddess' theme, can also be explored in terms of 'raw and cooked' opposition. For example, in Echtra mac nEchach Mugmedoin we find the same transformation of an animal/ monster into a beautiful king's lover, as we do in The Frog Princess. The shift from wilderness and madness to culture and sanity is performed by means of sexual intercourse. As Amy C. Eichhorn-Mulligan argues,

the text provides an arrestingly visual image of the hag's numerous long teeth that extend from her mouth to curve to the outside of her body; and by the grafting of animalesque tusks or horns onto her body, the lines between human and beast are blurred, and she constitutes a suitably wild opponent for the hero to overcome in his rise to Ireland's kingship. It is potentially of note that the term used, "benna buabaill" (horns of a buffalo), based on the typical employment of this natural material, also

17. As Gregory Toner has shown, this name is probably a later interpolation and the woman was not named in earlier versions of the tale. See Toner 2010: 85. I call this character Macha for convenience. 
signifies "drinking horn." The primary goal of the hornlike teeth is most likely to repulse in their wild incongruity on a woman's body; however, since this second descriptive passage immediately precedes the approach of the rightful king-to-be, the horns may also subtly remind the audience of the drink of sovereignty that she proceeds to offer Niall from a "royal horn" ("dind chuirn," p. 106). Like a wild buffalo's horns in the hands of an able craftsman, the ugly hag has the potential to be "tamed" and remade for productive social use [emphasis is mine], and as Niall lays his lips on hers, she is transformed.

(Eichhorn-Mulligan 2006: 1025-6)

We might recall here that both Mis and Mór Muman are fully restored to their senses after they spend a night with their lovers, Dub Ruis and Fíngin mac Áeda. Ó Riain (1972a: 196) also lists the act of coition "as a possible restorative occasion in terms of both madness and the novice", and cites the stories of Mis and Mór Muman as classical examples of this case (ibid.,202-3). The fact that, according to Mac Cana (1955-6:370-82), both women represent avatars of the sovereignty goddess links them with the goddess in Echtra mac nEchach Mugmedoin, and all three accounts can be considered realisations of the same theme: a beast-like/mad woman, alter ego of the sovereignty goddess, is restored to her beauty and sanity after the intercourse with a rightful king. ${ }^{18}$ Remarkably, according to Lévi-Strauss, the category of celibacy corresponds to the 'raw' element of the dichotomy (Lévi-Strauss 1964:340), and, in this vein, marriage is considered a transforming activity which performs the shift from immaturity to adulthood encoded in the basic binary opposition of 'raw' and 'cooked'.

The tales I have discussed feature a liminal creature - be it a frog, a supernatural woman, or a salmon - which possesses the essence of kingship (or of poetry, in Finn's case). Since the creature still belongs to the supernatural realm, the protagonist cannot yet access the magical substance contained within it. In order to obtain it, he needs to perform certain transforming actions which will make the Otherworld substance usable in this reality. ${ }^{19}$ Finn cooks the salmon; the wife

18. Note that the frog princess, who is also associated with the acquisition of kingship, turns into a beautiful lady only after the marriage with the young prince. The crucial role of the intercourse for the possibility of the union between a supernatural woman and a mortal man was discussed above on the basis of Macha and Crunnchu story. In general, this topos is well attested in world folklore and literature. For example, in the famous Undine by Friedrich de la Motte Fouqué, Undine needs to sleep with a man in order to obtain a human soul and to leave the supernatural world of the Rhine. She indeed gains a Christian soul after the first night with her husband, the knight Huldbrand: "Such as we are, however, can only obtain a soul by the closest union of affection with one of your human race. I am now possessed of a soul, and my soul thanks you" (Chapter VIII, cited after http://www.gutenberg.org/files/3714/3714-h/3714-h.htm\#chap08, last accessed on 9.05.2019).

19. According to Nagy, in Gaelic tradition water creatures like salmon, eel or otter are 'containers' 
of Eógan makes a cloak out of the salmon's wool; Niall, Dub Ruis and Fíngin spend a night with the threatening hag, Mis and Mór respectively, after which the women recover their sanity and their own appearance. The methodology of Lévi-Strauss allows us to discern a common pattern in these tales: cooking and sewing, as well as the act of coition function as civilising and socialising transformative processes which integrate the wild and untamed creature into the structures of human society and human relationships. Only when this is done, is the essence contained within a magical creature released, so that the hero can benefit from it.

\section{Tarbfheis and imbas forosnai elements}

Commenting on the story of Mis, who returns to sanity after eating a cooked deer, Joseph Nagy (1986-7:178) observes that "the treatment of this bereaved woman resembles other recorded Irish rituals that mark and/or effect transitions, including the mantic tarbfheis, 'bull-feast', and the bestial Tirconnell inauguration ceremony described by Gerald of Wales". Of course, putting on a skin of slain animal can be seen as an approximate analogue of Eógan's 'investiture'. The potential king fulfils his destiny as soon as the initiation rite is accomplished, and this accomplishment is transferred to a visual level by the symbolic change in clothes. The participant of the ritual, going through a symbolic rebirth, is to dispose of the 'old body' and accept his new shape; or, as Malamoud (1989: 60) puts it, "pour être en état de célébrer le sacrifice, le sacrificiant doit se dépouiller de son corps profane et se donner un corps sacrificiel." ${ }^{20}$

It would be too bold, perhaps, to emphasise the tarbfheis reflex in this episode of $T M$. What is really worth discussing is the nature of the salmon: being covered in wool, it occupies a liminal space between fish and mammal; it comes from the hidden corners of the universe to the observable world; it is a creature between worlds and species. In this sense, it mirrors the status of Eógan who passes through his initiatory ordeals, and cannot yet be defined or occupy an appropriate niche in society. He is going through the middle stage of his initiation/inauguration ritual and is just about to be ready for kingship. Moreover, he resides in a country which is not his own land, the passage being made from this world (Ireland) to the Otherworld (Spain). ${ }^{21}$ Both the salmon and the prince share the quality of

of either beneficent or destructive substances (e.g. imbas or poison): "these contents are usually released and utilised - that is, the animal container is penetrated, opened, even turned inside out, and/or transformed" (Nagy 1985-6:137).

20. 'In order to be able to celebrate the sacrifice, the sacrificer should divest himself of his profane body and provide himself with a sacrificial body' (translation is mine).

21. I have argued elsewhere that $T M$ is based on an echtra story-pattern, and that Spain in TM represents the Otherworld (Kudenko 2017). What I mean by this is that Spain is not the Otherworld per se (there are no indications thereof in the tale), but that Spain corresponds to what would normally 
liminality, "the state of being in between separate categories of space, time, or identity. A boy who is on the verge of manhood is a liminal figure, as is someone who crosses from the world into another" (Nagy 1981-2: 135).

Finn is also a young boy without any defined status and is therefore a liminal figure like Eógan. ${ }^{22} \mathrm{He}$ burns his finger while cooking and is suddenly enlightened after automatically putting his burned thumb into his mouth. This gesture can be compared with the technique of imbas forosna $i^{23}$ where a seer reached the necessary condition by chewing a piece of taboo meat. "The non-food is treated by the poet in search of knowledge as if it was edible; the morsel is a liminal object between the categories of edible and inedible" (Nagy 1981-2: 136). The same can be said about the salmon skin in our tale: since the wool is usually not found on a salmon, this feature can be seen as an argument for its liminality in TM. The liminal status of the object involved in the initiatory ritual corresponds to the liminal status of the participant of the rite. Besides, anomalous objects are believed to be sources of supernatural powers, and the cultural appropriation of these objects transmits their powers on the recipient. ${ }^{24}$ It is also important that the participants of the

be the Otherworld in other transmarine journeys and quests for brides (cf., for instance, Echtra Airt meic Cuind). The narrative elements of a given tradition are in paradigmatic relationship, which means that they are interchangeable, when they can potentially occupy the same slot in the narrative structure. Spain fills the same structural slot as the Otherworld in other echtrae, namely, 'the destination point of the hero's journey / the faraway land of the hero's initiation', and to this extent Spain in TM and the Otherworld are (structurally) equivalent to each other. Similarly, discussing the quest for the bride in the Otherworld or in Connacht, Ó Cathasaigh (1977:19) notes that "the tendency ... would be to describe both of these as Otherworld quests, one of them explicit, the other (the journey to Connaught) implicit."

22. Nagy $(1985: 124,126)$ stresses that the "gillacht (the state of being a gilla) is important to us in the study of Finn's youth because it is as a gilla that Finn becomes not only a full-fledged fénnid but also a poet $(f i l i)$... The gilla of medieval Irish literature is a liminal figure still in the process of being initiated into the status of adulthood." Cf. Murray 2017:144: "In Finn's appearances as gilla, we see him once more as a liminal figure awaiting adult status." There is a strong argument for the liminality of the fiana in general. Scowcroft (1987: 98) argues that the authors of the Fenian tales were "not only aware of liminality as an idea but more interested in its ramifications than in realistic narrative: prepared, in fact, to let liminal analogy and symbolism determine the plot." See also Murray (2017:53). Fenian warriors who live in the wilderness before settling within the confines of society represent Lévi-Strauss's shift from nature to culture and from youth to maturity. Charles Doherty (2005:5) describes the fiana as "an institution that prepared young men as warriors and presumably allowed the natural leaders of the next generation to emerge. Operating on the margins of society in the forests and wilderness, they returned to the settled community on reaching adulthood and on coming into their inheritance."

23. Literally, 'the great knowledge that enlightens'. On imbas and other mantic procedures of filid, see Carey 1997.

24. Cf. the following example from the Scottish folklore: "the virtual indestructibility of the righ nan dobhran [the King Otter] - his magical ability to survive - is actually transferred to the one who kills 
ritual, who are in liminal position themselves, interact with liminal objects in liminal areas. In the tarbfheis ritual the seer falls asleep on the threshold during the twilight. Finn is cooking the salmon on the bank of the Boyne. Likewise, the transformation of Eógan takes place near the Ebro.

Pádraig Ó Riain stresses the utmost importance of liminal areas in the worldview of Celtic people, arguing that "Cosmic Centre ... became in Celtic society a Cosmic Confine" (Ó Riain 1972b: 29). Thus, churches, royal settlements and professional organisations (e.g. schools of poetry) were located in boundary zones, and various important events, e.g. synods, fairs and inaugurations, were confined to boundary areas. Attributing the early Irish tendency to locate churches in border areas to a pre-Christian model, Ó Riain (1995: 146) writes elsewhere that "lying betwixt and between, boundary areas effectively belonged neither here nor there. As such, it was natural that they should have been regarded as areas of transition..." ${ }^{25}$ Therefore, liminal zones were regarded as middle ground between this world and the Otherworld, which explains why in the early Irish literature temporal and spatial boundaries serve as loci of fantastic occurrences. Liminal areas were especially prominent in "various rites de passage, or transition-rites, which figured in the career of the hero" and which formed "the substance of most of our early literature" (Ó Riain 1972b: 12).

As an example of such liminal areas, rivers are mentioned in Irish sources along with other natural boundaries (ibid.,17); and on a mythological level, a bank of the river becomes a spatial location for mystic revelations and metamorphoses. When Finn Éices and Demne are waiting for the salmon near the Boyne, they "are both interstitial figures, located on a physical and a metaphorical boundary" (Nagy 1985: 155):

the poet, seeking knowledge, is poised between land and water, and between this world - where the poet functions - and the source of imbas. Finn the Poet, the fisherman on the riverbank, remains incomplete ... the poet's gilla ... is himself by definition in a transitional stage of identity, between childhood and adulthood. These two figures in transit are waiting on the banks of a river (a boundary marker) for the salmon containing wisdom and inspiration, a fish that leaves its own world to swim to the borders of this world.

it and wears the pelt, a talisman which successfully contains and protects him" (Nagy 1985-6:125). 25. Interestingly, speaking of boundary zones, Ó Riain (1972b: 28) evokes Lévi-Strauss's idea that the aim of a myth "is to furnish a logical model for solving a contradiction." Contemplating this argument, Ó Riain concludes that "some such reasoning lay behind the Celtic concern with boundary areas. Apparently, the idea was to mediate" (ibid., 29). 
In early Irish tradition, rivers and lakes also often serve as sources of truth, wisdom and poetic knowledge. According to the tale Imacallam in Dá Thuarad, 'The Colloquy of Two Sages', inspiration was coming to poets at the brink of water (Wagner 1975: 1). To sum it up, "knowledge originates in a liminal source and comes to the poet in a liminal place. The seeker of knowledge must make himself a liminal figure in order to acquire imbas, and his liminality is reinforced after he receives it” (Nagy 1981-2: 139).

In addition to this, TM provides an important temporal marker which associates the salmon from our tale with Finn's salmon and the imbas. TM stresses the fact that the salmon comes to the waters of the Ebro every seventh year. As we know from $M F$, Demne's master Finn Éices has been waiting for seven years for the arrival of the salmon from Linn Féic (Meyer 1881-3: 201). The seven-year cycle is also mentioned in the 'Cauldron of Poesy' (\$11) in relation to the source of Segais, where imbas comes "in the middle of June every seventh year regularly" (Breatnach 1981: 66-7). Thus, when contextualised properly, the appearance of the salmon once in seven years in $T M$ points towards its connection with imbas.

There is another tale which supports the association of Eógan's salmon cloak with imbas. In a short account entitled Comracc Con Chulaind re Senbecc ua nEibricc a Segais, 'The Combat of Cuchulaind with Senbecc, grandson of Ebrecc, from Segais' (Meyer 1883-5: 182-4), Cú Chulainn performs his feats on the bank of the Boyne, catching the salmon of Linn Féic. Immediately afterwards, a small man called Senbecc appears in a boat and offers many gifts to the hero, inter alia, his shirt and cloak, explaining that "no decay comes upon them, nor upon him on whom they are, and any colour you like will be on them". The main motifs used in this account correspond to the constitutive elements of the salmon episode in $T M$. Senbecc comes into sight after the catching of the salmon, the provenance of which - Linn Féic - corresponds to the place from which the salmon of knowledge arrives to Finn in $M F$. Though Cú Chulainn is not portrayed as being in pursuit of imbas, we might presume that the granting of the cloak, with every colour in it, is related to the fact of catching the salmon. At least chronologically, the encounter with a little man follows Cú Chulainn's feat with the fish, and, therefore, clothes and other gifts which Cú Chulainn obtains from Senbecc might function as visualisations of the powers the Ulster hero has released after killing the bratán feasa.

The answer to the question who Senbecc was and what he was doing on the banks of the Boyne, is found in the opening sentence of the version B of this anecdote, preserved as part of the legal tract Bretha Nemed Dédenach. We learn that Senbecc was of the sid-folk, and that he came to the source of Segais in search of imbas (Senbheg ua Eibric a siodhaibh doluidh a muigh Seghaisi a ndeghaidh an iombais go ccomhairnig Cú Chulainn fris for Boinn (Gwynn 1942: 26-7)). However, as Gwynn, the editor of this account, notes, "the tale about Cú Chulainn and the elf Senbecc 
edited by Meyer in $R C$ vi 182 differs from ours in everything except the conclusion" (ibid., 222). Indeed, the plot is a different one but, nevertheless, it seems that it corroborates and complements version A by representing the meeting of the two figures with a focus on a different matter, the quest for imbas. Both versions, however, leave the question open whether Cú Chulainn came to the Boyne looking for imbas. The answer could be probably found in a short story from Harleian 5280 (Meyer 1912: 120). This account describes the circumstances of Cú Chulainn's visit to the Boyne in terms which correspond almost verbatim to the beginning of version A of the Comracc. As the tale begins, luid Cüculaind dorerim inbuis la Bóainn 'Cú Chulainn went to learn (? eDIL, s.v. rerim) imbas from the Boyne'. Thus, the aim of Cú Chulainn is explicitly mentioned - he comes to the river in search of imbas and, accordingly, catches the salmon.

The story of the encounter of Senbecc with Cú Chulainn contains the same combination of motifs (bank of the river, salmon, colourful cloak), and gives us another clue to the salmon episode in TM. The comparison of $M F, T M$ and the Comracc suggests that the salmon in our tale might be a variation on the bratán feasa, the interaction with which prompts the change or upgrade of the protagonist's status. Thus, yet again, the tales "se pensent entre eux": they are based on the common set of motifs and hence, serve as mirrors to each other. In the words of Northrop Frye (1957: 136), "the world of mythical imagery is ... a world of total metaphor, in which everything is potentially identical with everything else, as though it were all inside a single infinite body."

\section{Conclusion}

I hope to have demonstrated that the two salmon episodes in $T M$ and $M F$ can be presented through a common fundamental invariant which was elaborated into two different stories: the hero attains higher status after certain cultural activities transform the essence contained within the magical salmon. If we split the respective episodes into smaller segments, syntagmatic units, we will see that the underlying narrative structure of the stories of Finn and Eógan is almost identical.

$$
M F
$$

Knowledge, the new status, and the new name as the result of initiation are gained from the salmon, a liminal creature travelling between the worlds, which possesses wisdom contained within a hazel-nut (plant/fish liminal state).
$T M$

The new royal status, and the new name as the result of initiation are gained from the salmon, a liminal creature travelling between the worlds, which is covered in wool (fish/beast liminal state). 
The result of the interaction with the final product of the salmon is the acquisition of imbas, illuminating knowledge.

Enlightenment happens on the bank of the river, a liminal area between land and water.

The mediatory process of transforming the essence of knowledge into a usable

substance is cooking (transitional procedure which performs the change from the category 'raw/nature/Otherworld' to the category 'cooked/culture/ this world').

Finn is a liminal figure himself, a youth on the verge of manhood, a gilla ready to become a poet.
The result of the interaction with the final product of the salmon is a supernatural glow which reveals to his followers that Eógan is a lawful king.

Transformation happens on the bank of the river, a liminal area between land and water.

The mediatory process of transforming the magical essence hidden within the salmon into a usable substance is making a cloak out of the salmon skin (transitional procedure which performs the shift from the category 'raw/nature/ naked/Otherworld' to the category 'cooked/ culture/dressed/ this world').

Eógan is a liminal figure, a youth on the verge of manhood, a prince ready to become a king.

Significantly, all the elements involved in this syntagmatic chain have a liminal status. They create a specific liminal atmosphere - the only one in which the ritual, as well as the final transformation, becomes possible. The identical basic structure of the two episodes demonstrate that these two stories mirror and elucidate each other, or, to use the term of Lévi-Strauss, "se pensent entre eux". Eventually, they constitute a certain system because they both derive from the same store of literary motifs and story-patterns available in the Irish tradition.

Ulster University 


\section{References}

Afanasy'ev, A.N., 1985, ‘Царевна-лягушка: Сказка № 269' [The Frog Princess: Fairytale No. 269], in:Народные русские сказки А. Н. Афанасьева [Russian Folk Fairy-tales of A.N. Afanas'yev], Moscow, 264-7.

Breatnach, L., 1981, 'The Cauldron of Poesy', Ériu 32, 45-93.

Carey, J., 1997, 'The Three Things Required of a Poet', Ériu 48, 41-58.

Carey, J. \& Koch, J.T., 2003, The Celtic Heroic Age. Literary Sources for Ancient Celtic Europe and Early Ireland and Wales, 4th edition, Aberystwyth.

Carney, J., 2008, 'Literature in Irish, 1169-1534', in: Cosgrove, A., ed., A New History of Ireland: Volume II, Medieval Ireland 1169-1534, Oxford, 688-707.

Doherty, C., 2005 'Kingship in Early Ireland', in: Bhreathnach, E., ed., Tara: A Study of an Exceptional Kingship and Landscape, Maynooth, 3-29.

Duignan, L., 2011, The Echtrae as an Irish Literary Genre, Rahden/Westf.

Eichhorn-Mulligan, A.C., 2006, 'The Anatomy of Power and the Miracle of Kingship: The Female Body of Sovereignty in a Medieval Irish Kingship Tale', Speculum 81(4), 1014-54.

Findon, J., 2017, 'A Good Mortal Man is Hard to Find:Fand, Macha, Becfhola and Bad Romance', in: Ó Mainnín, M.B., \& Toner, G., eds., Ulidia 4: Proceedings of the Fourth International Conference on the Ulster Cycle of Tales, Dublin, 116-28.

Fomin, M., 2010a, 'The Land Acquisition Motif in the Irish and Russian Folklore Traditions', in:Brozović-Rončević, D., Fomin, M., \& Matasović, R., eds., Celts and Slavs in Central and Southeastern Europe, Zagreb, 251-79.

Fomin, M., 2010b, 'And His Cloak Covered the Whole Island: Legends of Religious Conversion (in Pali and Medieval Irish Traditions)', in: Fomin, M., Mac Mathúna, S. \& Vertogradova, V., eds., Sacred Topology of Early Ireland and Ancient India: Religious Paradigm Shift, Washington D.C., 195-239.

Frye, N., 1957, Anatomy of Criticism: Four Essays, Princeton.

Garnett, C. (trans.), 2005, Fyodor Dostoyevsky The Brothers Karamazov, New York.

Girard, R., 1977, 'Differentiation and Undifferentiation in Lévi-Strauss and Current Critical Theory', in: Krieger, M. \& Dembo, L.S., eds., Directions for Criticism: Structuralism and Its Alternatives, Wisconsin, 111-36.

Gwynn, E.J., 1942, 'An Old-Irish Tract on the Privileges and Responsibilities of Poets', Ériu 13, 1-60, 220-36.

Hughes, A.J., 1996, 'Some Aspects of the Salmon in Gaelic Tradition Past and Present', Zeitschrift für celtische Philologie 48, 17-28.

Isambert, F.-A., 1965, 'Lévi-Strauss Claude, Mythologiques. Le cru et le cuit. Compte rendu', Revue française de sociologie 6(3), 392-4.

Knott, E., 1922, The Bardic Poems of Tadhg Dall Ó hUiginn (1550-1591), Vol. I. Introduction and Text, London. 
Knott, E., 1936, Togail Bruidne Da Derga, Dublin.

Kudenko, K., 2017, 'Tochmarc Moméra as Echtra to the Otherworld', Studia Celtica Fennica 14, 94-112.

Lévi-Strauss, C., 1964, Le cru et le cuit, Paris.

Lévi-Strauss, C., 1966, The Savage Mind, Chicago.

Lévi-Strauss, C., 1970, The Raw and The Cooked, London.

Lévi-Strauss, C., 1971, L'homme nu, Paris.

Lévi-Strauss, С., 2007, Мифологики: Человек голый [Mythologies: The Naked Man], Moscow. Lotman, Yu., 2000, 'Внутри мыслящих миров. Часть вторая. Символические пространства' [Inside the Thinking Worlds. Part 2. Symbolical Spaces], in: Семиосфера [The Semiosphere], St. Petersburg, 297-333.

Mac Cana, P., 1955-6, 'The Theme of King and Goddess in Old Irish Literature', Études Celtiques 7, 76-114, 356-413.

Mac Cana, P., 1999, 'The Irish Analogues of Mélusine', in: Lysaght, P., Ó Catháin, S., \& Ó hÓgáin, D., eds., Islanders and Water-Dwellers, Dublin, 149-64.

Malamoud, C., 1989, Cuire le monde. Rite et pensée dans l'Inde ancienne, Paris.

McManus, D., 2009, 'Good-looking and Irresistible: The Hero from Early Irish Saga to Classical Poetry”, Ériu 59, 57-109.

Meyer, K., 1881-3, 'Macgnimartha Find', Revue Celtique 5, 195-204.

Meyer, K., 1883-5, 'Irish Miscellanies: Anecdota from the Stowe MS. n’ 992', Revue Celtique 6, 173-86.

Meyer, K., 1904, 'The Boyish Exploits of Finn,' Ériu 1, 180-90.

Meyer, K., 1912, 'Die Ursache von Noinden Ulad', Zeitschrift für celtische Philologie 8, 120. Murray, K., 2017, The Early Finn Cycle, Dublin.

Nagy, J.F., 1980, 'Intervention and Disruption in the Myths of Finn and Sigurd', Ériu 31, 123-31.

Nagy, J.F., 1981, 'Demne Mael', Celtica 14, 8-14.

Nagy, J.F., 1981-2, 'Liminality and Knowledge in Irish Tradition', Studia Celtica 16-17, 135-43.

Nagy, J.F., 1984, 'Heroic Destinies in the Macgnimrada of Finn and Cú Chulainn', Zeitschrift für celtische Philologie 40, 23-39.

Nagy, J.F., 1985, The Wisdom of the Outlaw: the Boyhood Deeds of Finn in Gaelic Narrative Tradition, Berkeley.

Nagy, J.F., 1985-6, 'Otter, Salmon and Eel in Traditional Gaelic Narrative', Studia Celtica 20-1, 123-44.

Nagy, J.F. 1986-7, 'Fenian Heroes and Their Rites of Passage', Béaloideas 54-5, 161-82. Ó Cathasaigh, T., 1977, The Heroic Biography of Cormac Mac Airt, Dublin.

Ó Coileáin, S., 1974, 'The Structure of a Literary Cycle', Ériu 25, 88-125.

Ó Corráin, D., 1986, 'Historical Need and Literary Narrative', in: Evans, D.E., Griffith, J.G., \& Jope, E.M., eds., Proceedings of the Seventh International Congress of Celtic Studies, Oxford, 141-58. 
Ó Cuív, B., 1954, 'The Romance of Mis and Dubh Ruis,' Celtica 2, 325-33.

Ó Cuív, B., 1983, 'A Poem Composed for Cathal Croibhdhearg Ó Conchubhair', Ériu 34, 157-74.

O'Curry, E., 1855, Cath Mhuighe Léana or The Battle of Magh Leana, Together with Tochmarc Moméra or the Courtship of Moméra, Dublin.

O'Kearney, N., 1855, Feis Tighe Chonain Chinn-Shleibhe, or The Festivities at the House of Conan of Ceann-Sleibhe in The Country of Clare, Dublin.

O'Keeffe, J.G., 1913, Buile Suibhne: The Frenzy of Suibhne, London.

O’Nolan, T.P., 1912-3, 'Mór of Munster and The Tragic Fate of Cuanu son of Cailchin', Proceedings of the Royal Irish Academy 30 (C), 261-82.

O’Rahilly, C., 1976, Táin Bó Cuailnge. Recension I, Dublin.

Ó Riain, P., 1972a, 'A Study of the Irish Legend of the Wild Man', Eigse 14, 179-206.

Ó Riain, P., 1972b, 'Boundary Association in Early Irish Society', Studia Celtica 7, 12-29.

Ó Riain, P., 1995, 'Pagan Example and Christian Practice: a Reconsideration', in: Edel, D., ed., Cultural Identity and Cultural Integration: Ireland and Europe in the Early Middle Ages, Dublin, 144-56.

Partridge, A., 1980, 'Wild Men and Wailing Women', Éigse 18, 25-37.

Plummer, C., 1922, Bethada Náem nÉrenn: Lives of Irish Saints, Vols. I, II, Oxford.

Rees, A. \& Rees, B., 1961, Celtic Heritage: Ancient Tradition in Ireland and Wales, London.

Ritari, K., 2006, 'Images of Ageing in the Early Irish poem Caillech Bérri', Studia Celtica Fennica 3, 57-70.

Scowcroft, R.M., 1987, 'On Liminality in the Fenian Cycle [Review of: Nagy, J. F., 1985, The Wisdom of the Outlaw: The Boyhood Deeds of Finn in Gaelic Narrative Tradition, Berkeley]', Cambridge Medieval Celtic Studies 13, 97-100.

Scowcroft, R.M., 1995, 'Abstract Narrative in Ireland', Ériu 46, 121-58.

Sjoestedt, M.-L., 1940, Dieux et Héros des Celtes, Paris.

Sjoestedt, M.-L., 1949, Gods and Heroes of the Celts, tr. Myles Dillon, London.

Sproule, D., 1985, 'Politics and Pure Narrative in the Stories about Corc of Cashel', Ériu 36, 11-28.

Stokes, W., 1900, 'Acallamh na Senórach', in:Windisch, E., \& Stokes, W., eds., Irische Texte mit Wörterbuch, vol. 4:1, Leipzig, 1-438, ix-xiv.

Stokes, W., 1901, 'The Destruction of Dá Derga's Hostel', Revue Celtique 22, 9-61, 165-215, 282-329, 390-437, 260 (erratum).

Toner, G., 2010, 'Macha and the Invention of Myth', Ériu 60, 81-109.

Van Gennep, A., 1960, The Rites of Passage, Chicago.

Wagner, H., 1975, 'Studies in the Origins of Early Celtic Traditions', Ériu 26, 1-26.

Watson, A., 1986, 'A Structural Analysis of Echtra Nerai', Etudes Celtiques 23, 129-42.

Zafiropoulos, M., 2010, Lacan and Levi-Strauss or The Return to Freud (1951-1957), London. 
